Carreira, O. (2021). The Girl Up Project: A Proposal to Teach Transcreation and Project Management Skills. Current Trends in Translation Teaching and Learning E, 8, 86 - 123. https://doi.org/10.51287/cttle2021

\title{
THE GIRL UP PROJECT: A PROPOSAL TO TEACH TRANSCREATION AND PROJECT MANAGEMENT SKILLS
}

Oliver Carreira

Pablo de Olavide University | Interglosia RG

\begin{abstract}
Technology is quickly disrupting the language services industry. These abrupt changes may worsen the employability of translation students, who require new skills to adapt to this changing market.

Transcreation, a type of creative translation that mostly takes place in the marketing and advertising areas, can be an empowering area for students in terms of professional development and employability.

To familiarize undergraduate translation students with transcreation practices, we have developed the "Girl Up Project": a situated training initiative oriented to consolidate theoretical concepts on the topic, develop their organizational and creative skills, improve their teamwork abilities and establish a clear connection between the training initiative and the industry.
\end{abstract}


Carreira, O. (2021). The Girl Up Project: A Proposal to Teach Transcreation and Project Management Skills. Current Trends in Translation Teaching and Learning E, 8, 86 - 123. https://doi.org/10.51287/cttle2021

The outcomes of the project seem to confirm that this type of initiative is useful to improve the knowledge of students on transcreation and transcreation project management skills.

Keywords: transcreation, translation training, situated learning, employability, simulated projects

\section{INTRODUCTION}

During the last decades, technology has played an essential role in professional translation and the language services industry (O'Hagan, 2016). Different software platforms, such as computerassisted tools (García, 2009), localization tools (Esselink, 2003), globalization management systems (Yunker, 2002), and translation environment tools (Bowker \& Fisher, 2013), have allowed translators to be more productive and to improve the quality of the texts they produce.

While some of these tools were welcomed in the past by some language professionals with reluctance, lack of enthusiasm, and even hostility (Dillon \& Fraser, 2007), as they were perceived as negative for their job status and conditions, the widespread implementation of technology in the industry has allowed the language professionals to face the enormous growth of content production that has 
Carreira, O. (2021). The Girl Up Project: A Proposal to Teach Transcreation and Project Management Skills. Current Trends in Translation Teaching and Learning E, 8, 86 - 123. https://doi.org/10.51287/cttle2021

taken place during the last two decades (Williams, 2017).

Thanks to the different technology developments mentioned above, language professionals have been able to increase their productivity and the quality of their work (Doherty, 2016). However, these improvements have not always had as a consequence better working conditions. The hard truth is that translators are being pressured to contain or reduce their rates. Due to rising competition and pressure from clients and agencies, language professionals are being paid less in many cases (Courney \& Phelan, 2019). This situation has led to the notion that translation is a commodity like many others. In this sense, translators are sometimes perceived as interchangeable and replaceable (Liu, 2014; Moorkens, 2017).

The scenario described above has worsened due to a more recent technology that has disrupted the market: neural machine translation (NMT). With the introduction of this type of machine translation, "what was rare has become accessible everywhere and anytime, what was expensive is now free" (Larsonneur, 2021, p. 258). NMT provides levels of quality perceived by native speakers to be of equivalent quality to the translations produced by human translators, even in the case of creative 
Carreira, O. (2021). The Girl Up Project: A Proposal to Teach Transcreation and Project Management Skills. Current Trends in Translation Teaching and Learning E, 8, 86 - 123. https://doi.org/10.51287/cttle2021

practices such as literary translation (Toral \& Way, 2018).

The situation we have described seems to portrait a gloomy and dark panorama for language professionals and, more specifically, for translation students. However, and despite all the recent technology developments we have detailed above, there are still interesting opportunities for professional development in areas where the skills that translation students acquire during their training are in high demand. In this sense, they need "to become the sort of translator who can produce highquality translations which a machine can never produce. This kind of translation is often categorized as 'creative' translation in both the industry and academia. One often-discussed area of such work is 'transcreation"' (Sakamoto, 2021, p. 248-249).

This paper is aimed to offer a general view on transcreation as a service in the language industry, the opportunities that this practice offers to translation students in terms of employability and professional development, and how transcreation teaching can be integrated into existing undergraduate programs. For this purpose, we will describe a didactic proposal known as the "Girl Up Project". 
Carreira, O. (2021). The Girl Up Project: A Proposal to Teach Transcreation and Project Management Skills. Current Trends in Translation Teaching and Learning E, 8, 86 - 123. https://doi.org/10.51287/cttle2021

\section{THE CONCEPT OF TRANSCREATION AND ITS POTENTIAL FOR STUDENTS}

There are different approaches to the concept of transcreation. A good starting point is the definition provided by TAUS (2019, p. 8): "It can be defined as a translation that is enhanced by creativity and focus on style, register, and emotive impact, and modified to suit a new audience which can be a group of users, a country, a region, etc. Typically, it covers advertising, banners, slogans, word logos. [...] Transcreation is found most often in advertising content, or brand-orientated content, where the principal aim is to sell to customers, and where taglines or straplines often require intensive reworking." Transcreation implies a creative adaptation that gives priority to the effect and impact caused in the intended audience (Pedersen, 2014). In this sense, it has strong connections with other creative writing services, such as copywriting (Benetello, 2018; Sattler-Hovdar, 2019).

This is not the only view on transcreation. Some scholars consider this practice a strategy that can be applied in different modalities of intersemiotic transfer, such as audiovisual translation (Malenova, 2017: Chaume, 2018), videogame localization 
Carreira, O. (2021). The Girl Up Project: A Proposal to Teach Transcreation and Project Management Skills. Current Trends in Translation Teaching and Learning E, 8, 86 - 123. https://doi.org/10.51287/cttle2021

(Mangiron \& O'Hagan, 2006; Crosignani \& Ravetto, 2011), or literature (Lal, 1996; De Campos, 2013; Glance \& Jaccomard, 2019; Dybiec-Gajer et al., 2020) among others. Other scholars defend the idea that this term provides little or no value to translation studies (Bernal Merino, 2006) and fear its destabilizing effect on the discipline (Munday and Gambier, 2014).

For the purposes of this paper, we will refer to transcreation as described by TAUS. This means, a service provided by the language industry, that offers language professionals the possibility to "make the transcreational turn" (Katan, 2016, p. 378). This means that they have the opportunity to leave behind the possibility of competing versus machines in the language industry and transition to a more creative role. This transcreational turn takes place around three points that make transcreation attractive to both professionals and students: creativity, added value, and the potential to go beyond translation.

\subsection{Transcreation is an Added-Value Service}

Transcreation is not just another service in the industry: it is an added-value one. It has been included as such in a non-exhaustive list included in standard ISO 17100:2015. Likewise, Pedersen 
Carreira, O. (2021). The Girl Up Project: A Proposal to Teach Transcreation and Project Management Skills. Current Trends in Translation Teaching and Learning E, 8, 86 - 123. https://doi.org/10.51287/cttle2021

(2014) confirmed in his ethnographic study that transcreation is perceived as such by professionals of the language services industry.

But, what do we mean by "added-value service"? According to Chernatony et al. (2000), there are different perceptions of the term:

- Jones (1986) claims that added value services are key elements to define a brand and distinguish it from a product (Jones, 1986).

- According to Grönroos (1997), a service is made of basic and added elements. The last ones are considered as added value.

- McCraken (1993) establishes that added value services play a role in the process of expectations definitions by customers.

- Normann \& Ramirez (1994) speak about the role that added value services play to guarantee competitive advantage.

These perceptions about added-value services are linked to positive skills for translation students in terms of employability. Again, by offering them transcreation training, we can improve their future competitivity in the market. 
Carreira, O. (2021). The Girl Up Project: A Proposal to Teach Transcreation and Project Management Skills. Current Trends in Translation Teaching and Learning E, 8, 86 - 123. https://doi.org/10.51287/cttle2021

\subsection{Transcreation as a Way to Go Beyond}

Morón Martín (2020, p. 126) states that transcreation training allows "exposing students to the need to do something else other than just translating." As we have seen in previous sections, students need to be ready to go beyond translation, an area that will probably be dominated in the future by machine translation. In this sense, transcreation training seems to be a useful option for them, as it allows to creatively foster their employability and career pathways inside and around translation (Koskinen \& Dam, 2016).

\subsection{The Need for Further Research in Transcreation Training}

In the three previous sections, we have provided arguments that seem to confirm that transcreation training is a useful approach to make translation students competitive in the language services industry and to ease their employability. Despite this fact, the number of initiatives in this sense is reduced. On one hand, we find the TeCreaTe project (Morón \& Calvo, 2018; Morón \& Lobato, 2019), an undergraduate initiative focused on fashion. On the other, a collaborative project, integrated into a career-competences module for undergraduate 
Carreira, O. (2021). The Girl Up Project: A Proposal to Teach Transcreation and Project Management Skills. Current Trends in Translation Teaching and Learning E, 8, 86 - 123. https://doi.org/10.51287/cttle2021

students (Huertas Barros \& Vine, 2019). Finally, Botella Tejera et al. (2021) propose a workshop oriented to audiovisual translation postgraduate students.

Each of these three proposals focus on specific elements of a standard transcreation workflow. We believe it would be important to develop an integrated approach including the different steps involved in this type of project. For this purpose, we describe the following didactic proposal.

\section{DESCRIPTION OF THE DIDACTIC PROPOSAL}

The Girl Up Project is a training initiative oriented to develop the transcreation skills of undergraduate students. This took part during the academic year 2020-2021. The project is part of the course "Specialized Translation: English C Language" with a teaching load of 6 ECTS. This course is divided into four modules (Legal Translation, Sworn Translation, Commercial and Economic Translation, and Transcreation) and is taught in the final year of the 4-year BA in Translation and Interpreting Studies program at Pablo de Olavide University (Seville, Spain). 
Carreira, O. (2021). The Girl Up Project: A Proposal to Teach Transcreation and Project Management Skills. Current Trends in Translation Teaching and Learning E, 8, 86 - 123. https://doi.org/10.51287/cttle2021

The Transcreation module is divided into two parts. On one hand, 9 hours of training, which include both a theoretical introduction (including concepts such as transcreation itself, brief, back-translation, rationale, transcreation workflows, etc.) and a series of practical exercises. On the other, and once the students have acquired the basic skills required to face this type of creative adaptation tasks, they start to work on the Girl Up project.

Girl Up (https://girlup.org/) is an initiative led by United Nations to empower girls and teenagers to be a force for gender equality and social change, mostly focusing on leadership development. The website of this initiative is available in several languages, including Spanish. We considered that the quality of the existing version could be improved and this served as the basis for the project.

The following simulated situation is described to the students: United Nations has published an invitation to tender to improve the contents of the Spanish version of the Girl Up project. The invitation is open to any transcreation agency, that must submit a series of materials to have their candidacy assessed. Working in groups whose members are randomly selected (to simulate a close to reality experience), the students assume the role of a transcreation agency interested in winning the tender. For this 
Carreira, O. (2021). The Girl Up Project: A Proposal to Teach Transcreation and Project Management Skills. Current Trends in Translation Teaching and Learning E, 8, 86 - 123. https://doi.org/10.51287/cttle2021

purpose, they must provide the following deliverables:

- A report on the existing version of the website: with a maximum of 500 words, students must describe the elements that must be corrected, the ones that can be improved, and any sociocultural aspect that must be taken into account for the transcreation process. The objective of this deliverable is to assess the analytic skills of the students and their ability to determine the most important elements since the document has a length restriction. Writing this report also forces the students to carry out an analysis that facilitates further steps.

- A transcreation brief: students must write the transcreation brief that would be used in case they would win the tender. They must take into account that this brief might be used either internally by them, as workers of the transcreation agency they belong to, or externally by freelance providers of the company. For this purpose, they must apply what they have learned on transcreation briefs during the training sessions of the module.

- A series of transcreated contents: students must provide transcreation options 
Carreira, O. (2021). The Girl Up Project: A Proposal to Teach Transcreation and Project Management Skills. Current Trends in Translation Teaching and Learning E, 8, 86 - 123. https://doi.org/10.51287/cttle2021

(including back-translation and rationale for each one of them) for a series of elements that are either left in English in the Spanish version or that require a rewriting of the existing version.

- A public presentation of their candidacy: the group must present their work in a 15 minutes public presentation, where the lecturer and the rest of the students take the role of "UN jury" for the different proposals, offering feedback and making comments and questions that must be answered by the group.

Together with the specific training on transcreation received during the initial sessions of the module, students are given a detailed explanation about the nature of the project and expected outcomes, as well as a series of materials: a document with instructions, a series of brief templates and a pre-formatted Excel file, that includes all the contents that they must transcreate and a series of fields to provide their transcreation options, back-translation, and rationale for each one of them.

The objectives of the "Girl Up Project" were the following: 
Carreira, O. (2021). The Girl Up Project: A Proposal to Teach Transcreation and Project Management Skills. Current Trends in Translation Teaching and Learning E, 8, 86 - 123. https://doi.org/10.51287/cttle2021

- Consolidating the acquisition of concepts such as transcreation, brief, back-translation, and rationale among others.

- Developing the organizational and creative skills required to face any of the stages involved in a transcreation workflow.

- Improving teamwork skills and showing the students the importance of these in a professional setting.

- Establishing a clear connection between the academic/training and professional areas (something particularly important for lastyear students) and showing the students the career opportunities available in the transcreation area.

From a theoretical point of view, the proposal follows a functionalist (Nord, 1991; Vermeer, 1996) and constructivist approach (Kiraly, 2000). The idea was to develop a practical and situated training project (Kiraly 2005, 2016; Calvo, 2015, among others) that could be perceived as realistic and connected with the demands of the industry.

\section{RESULTS}

A total of 43 students took part in the project. They were randomly divided into 9 groups. After the initial training sessions, they had 8 weeks to provide 
Carreira, O. (2021). The Girl Up Project: A Proposal to Teach Transcreation and Project Management Skills. Current Trends in Translation Teaching and Learning E, 8, 86 - 123. https://doi.org/10.51287/cttle2021

the deliverables described in the previous section (report, brief, and transcreated contents; the public presentation takes place four weeks later due to organizational issues related to the structure of the course). The project is rated on a scale of 1 to 10 , where 10 is the highest grade achievable. A different punctuation is assigned to each element (as described below). In the following sections, we detail the outcomes for each of the requested deliverables and the main challenges found.

\subsection{Report}

To assess this section, we carried out an analysis of the Spanish version of the Girl Up site to determine which points should be appearing in the students' reports. All the issues found were grouped in five categories: 1) untranslated content (partially or totally), 2) localization issues (related to regional settings such as dates, currency, etc.), 3) style (expressions deemed as not natural in Spanish-Spain or with a style not fitting the expected target), 4) orthotypography (spelling issues and wrong use of punctuation marks), and 5) lack of adaptation of hyperlinks (this included both links of the Spanish version pointing to the English version and social media links pointing to the English-speaking accounts for these). To obtain the maximum punctuation in this section (2 over 10), students had 
Carreira, O. (2021). The Girl Up Project: A Proposal to Teach Transcreation and Project Management Skills. Current Trends in Translation Teaching and Learning E, 8, 86 - 123. https://doi.org/10.51287/cttle2021

to mention in their reports at least one example belonging to each of these categories. Another requisite was that the report had to be under 500 words (this was included to simulate the need to follow detailed instructions, which are usually present in this type of projects).

Only one of the groups included issues for all the categories, while three groups missed 1 of the categories, four groups missed 2 of the categories and one group missed 3 of the categories.

\subsection{Brief}

To assess this section, students were expected to include at least the most frequent sections found in a standard transcreation brief (Carreira, 2020). These were explained during the training sessions: values and mission (the characteristics that guide the Girl Up initiative and its objectives), voice (how the expected public of the initiative should be addressed), target (segmentation by age, gender, socioeconomic status, etc.), format and media (the elements used by the campaign, such as video, graphics, etc. and the platform where they will be published, such as websites, social media, etc.), and instructions/restrictions (any additional information that the recipient of the transcreation brief should know). 
Carreira, O. (2021). The Girl Up Project: A Proposal to Teach Transcreation and Project Management Skills. Current Trends in Translation Teaching and Learning E, 8, 86 - 123. https://doi.org/10.51287/cttle2021

2 of the 9 groups did not include one or several of the expected sections. The remaining 7 groups included them, though the results were mixed: in some cases, there was missing information (for example, in one case, in the "values and mission" section, the values were not included), it was incomplete (for example, not including in the "voice" section if formal or informal style should be used) or was incorrect (for example, a wrong age segmentation in the "target" section). Other issues include a bad structure in the document (not including an introduction or positioning the different sections in an illogical order) or just filling the brief templates provided (that were intended only as a general guide to write a transcreation brief document; this was specifically mentioned to the students during the training sessions).

\subsection{Transcreated Contents}

This was the core of the project. Students had to provide one transcreation option for the tagline Girl Up (kept in English in the existing Spanish version of the website), three transcreation/rewriting options for the sentence When girls rise, we all rise (already translated into Spanish as Las niñas son el motor del movimiento por la igualdad de género; this option was deemed as not-appealing and students were 
Carreira, O. (2021). The Girl Up Project: A Proposal to Teach Transcreation and Project Management Skills. Current Trends in Translation Teaching and Learning E, 8, 86 - 123. https://doi.org/10.51287/cttle2021

asked to improve it) and three transcreation options for the social media hashtag \#TodayWeRise! (in English in the existing version). By asking the students to face different types of transcreation tasks and texts, we wanted to expose them to the different issues that can be found in a real transcreation project (many of these were already covered in previous training sessions). In Table 1, we can see some representative examples of the options provided by the students.

Table 1. Some Transcreation Options Provided by the Students

\begin{tabular}{|c|c|c|}
\hline Original & Transcreation & Back-Translation \\
\hline \multirow{3}{*}{ Girl Up } & Juntas volamos & Together we fly \\
\hline & Chicas al poder & Girls to power \\
\hline & Todas a una & All for one \\
\hline \multirow{3}{*}{ When girls rise, } & $\begin{array}{c}\text { Cuando una gana, todas } \\
\text { ganamos }\end{array}$ & $\begin{array}{c}\text { When one wins, we all } \\
\text { win }\end{array}$ \\
\hline & $\begin{array}{c}\text { Si nosotras avanzamos, } \\
\text { la humanidad avanza }\end{array}$ & $\begin{array}{l}\text { If we move forward, } \\
\text { humanity moves } \\
\text { forward. }\end{array}$ \\
\hline & $\begin{array}{c}\text { El cambio empieza } \\
\text { desde pequeñas }\end{array}$ & $\begin{array}{c}\text { Change starts when } \\
\text { girls are little }\end{array}$ \\
\hline \multirow{3}{*}{ \#TodayWeRise } & \#TodasLuchamos & \#WeAllFight \\
\hline & \#VuelaAlto & \#FlyHigher \\
\hline & \#TodasAUna & \#AllToOne \\
\hline
\end{tabular}


Carreira, O. (2021). The Girl Up Project: A Proposal to Teach Transcreation and Project Management Skills. Current Trends in Translation Teaching and Learning E, 8, 86 - 123. https://doi.org/10.51287/cttle2021

The assessment of this section specifically excluded the evaluation of the creative aspect of the transcreation proposals for two reasons. On one hand, the degree of inherent creativity of each student is a variable that we cannot control. On the other, the evaluation of creative works implies a subjective approach that goes against the type of objective evaluation that is expected in an academic environment. Taking into consideration these motives, we decided to only take into account those elements deemed as objective, i.e., that the students would fill correctly the transcreation file provided. 8 of 9 students carried out this task correctly. The remaining one placed the transcreation option and the corresponding back-translation for Girl Up in wrong cells. Likewise, all groups had points detracted due to the presence of spelling mistakes and typos.

\subsection{Public Presentation}

After delivering the previous materials, each group had to defend their proposals in a 15 minutes presentation, followed by a 5 minutes turn for questions and a series of feedback comments by the lecturer. The assessment criteria applied for this section were: 1) following a logical structure for the presentation, 2) completing the task in the assigned 
Carreira, O. (2021). The Girl Up Project: A Proposal to Teach Transcreation and Project Management Skills. Current Trends in Translation Teaching and Learning E, 8, 86 - 123. https://doi.org/10.51287/cttle2021

time, and 3) providing reasoned answers to the questions made by other students.

The main purpose of this deliverable was to simulate the interaction that takes place between a transcreator and a client when they have to defend a creative proposal (and develop the skills required to do so). Likewise, the interaction between the groups defending the proposals, the students posing questions, and the lecturer providing feedback allowed the development of spontaneous discussions which were quite productive for all the agents involved from a didactic point of view.

\subsection{Evaluation Outcomes and Reception of the Project by the Students}

Despite the issues and mistakes found in the different sections of the project that have been detailed above, the evaluation outcomes can be considered positive. The 43 students passed and the grades obtained ranged between 6.3 and 7.6 over 10 .

To confirm if the expected objectives of the project were met, we asked the students to complete a short, anonymous survey. 29 out of 43 participants answered the following questions, detailed in Table 2 below. 
Carreira, O. (2021). The Girl Up Project: A Proposal to Teach Transcreation and Project Management Skills. Current Trends in Translation Teaching and Learning E, 8, 86 - 123. https://doi.org/10.51287/cttle2021

Table 2. Questions and Answers from the Satisfaction Survey on the Girl Up Project

\begin{tabular}{|c|c|c|}
\hline \multirow{2}{*}{ Question } & Answer Options & Number \\
of & Answers \\
\hline \hline \multirow{2}{*}{$\begin{array}{c}\text { How would you define your level of } \\
\text { knowledge about the concept } \\
\text { "transcreation" after completing the } \\
\text { project? }\end{array}$} & It has improved & 22 \\
\cline { 2 - 3 } & It has worsened & 0 \\
\hline \hline \multirow{2}{*}{$\begin{array}{c}\text { How would you define your level of } \\
\text { knowledge about transcreation } \\
\text { project management after } \\
\text { completing the project? }\end{array}$} & It has improved & 7 \\
\cline { 2 - 3 } & It has worsened & 1 \\
\cline { 2 - 3 } $\begin{array}{c}\text { What is your perception about } \\
\text { transcreation career opportunities } \\
\text { after completing the project? }\end{array}$ & It is the same & 0 \\
\cline { 2 - 3 } & It has improved & 21 \\
\cline { 2 - 3 } & It is the same & 8 \\
\hline \hline \multirow{2}{*}{$\begin{array}{c}\text { How would you define your team } \\
\text { working skills after completing the } \\
\text { project? }\end{array}$} & They have improved & 14 \\
\cline { 2 - 3 } project? & They have worsened & 0 \\
\cline { 2 - 3 } & They are the same & 15 \\
\hline \hline \multirow{2}{*}{$\begin{array}{c}\text { How would you define your } \\
\text { creative skills after completing the }\end{array}$} & They have improved & 22 \\
\cline { 2 - 3 } & They have worsened & 0 \\
\cline { 2 - 3 } & They are the same & 7 \\
\hline \hline
\end{tabular}

If we use the perceptions of the students as an indication of the effectiveness of the project, we may claim that the results are mostly positive. Most of the students report an improvement of their perception of the different items. The area where higher progress has been achieved is familiarity with 
Carreira, O. (2021). The Girl Up Project: A Proposal to Teach Transcreation and Project Management Skills. Current Trends in Translation Teaching and Learning E, 8, 86 - 123. https://doi.org/10.51287/cttle2021

transcreation project management (28 positive answers) while the one where the progress is not that high is team working skills development (14 positives). The lower result in this area might be related to the fact that students had to work with groups whose members were not chosen by themselves (like in a professional environment).

To provide space for the students to show their feedback more openly, a sixth question was included: "what did you like the most and least about the project? And what elements could be improved?". The answers to this question are summarized in Table 3. 
Carreira, O. (2021). The Girl Up Project: A Proposal to Teach Transcreation and Project Management Skills. Current Trends in Translation Teaching and Learning E, 8, 86 - 123. https://doi.org/10.51287/cttle2021

Table 3. Most and Least Liked Elements of the Project + General Feedback

\begin{tabular}{|c|c|c|}
\hline Most Liked Elements & Least Liked Elements & General Feedback \\
\hline $\begin{array}{l}\cdot \text { Team working and } \\
\text { adapting the content } \\
\text { to a target. } \\
\text { - Working with new } \\
\text { people. } \\
\text {-Creative work and } \\
\text { freedom. } \\
\text { - Working on a } \\
\text { realistic project. } \\
\text { - The social aspects of } \\
\text { the project. } \\
\text { - Being able to } \\
\text { provide a transcreated } \\
\text { option. }\end{array}$ & $\begin{array}{l}\text {-Working with people } \\
\text { not involved in the } \\
\text { project. } \\
\text { ·Finding a rationale to } \\
\text { explain why a } \\
\text { transcreation option } \\
\text { was chosen. } \\
\text {-Creative block. } \\
\text { ·Working with people } \\
\text { I did not know/I did } \\
\text { not choose. } \\
\text {-Writing the report. } \\
\text {-Deadlines (I had to } \\
\text { work in other courses } \\
\text { at the same time) }\end{array}$ & $\begin{array}{l}\text { Confusing } \\
\text { instructions. } \\
\text {-It would be } \\
\text { interesting to choose } \\
\text { the contents to be } \\
\text { transcreated. } \\
\text { - Theorical contents } \\
\text { were not enough. }\end{array}$ \\
\hline
\end{tabular}

Most of the answers by the students are positive. Concerning the least liked elements, it seems they do not point to a bad design of the didactic project and are somehow understandable, since they voice some of the frustrations of the students. For example, they did not like working in random groups (though this is important, since that will be the work dynamic in a professional environment).

Finally, there are several improvement suggestions that are quite interesting. First of all, 3 participants mentioned that the instructions were confusing. 
Carreira, O. (2021). The Girl Up Project: A Proposal to Teach Transcreation and Project Management Skills. Current Trends in Translation Teaching and Learning E, 8, 86 - 123. https://doi.org/10.51287/cttle2021

During the course, students asked about several points of the instructions that were not clear or required further explanations. We have taken this into account to rewrite the instructions document for future editions of the project. Secondly, students mentioned that theoretical contents were not enough. We were aware of this, but the credit distribution of the course is something that the lecturers cannot modify without previous authorization by the corresponding department (an option to explore that mostly requires administrative work). Finally, students proposed to have several content options to choose from. This will be considered, though any change in this sense must be carefully considered, as it raises some doubts in terms of guaranteeing a uniform and objective evaluation for all the participating groups.

\section{CONCLUSIONS}

We believe the described didactic proposal has met all the stated objectives with a relatively good level of success. By doing so, we believe that the "Girl Up Project" can be a useful tool to empower students through the acquisition of transcreation skills: a knowledge that allows them to improve their employability and make them more competitive in a professional environment where technology is quickly changing what we understand as 
Carreira, O. (2021). The Girl Up Project: A Proposal to Teach Transcreation and Project Management Skills. Current Trends in Translation Teaching and Learning E, 8, 86 - 123. https://doi.org/10.51287/cttle2021

"translation." The results, both in terms of grades obtained and satisfaction shown, point to the fact that, with some minor improvements, the Girl Up project can be easily implemented in any undergraduate translation/transcreation training program. 
Carreira, O. (2021). The Girl Up Project: A Proposal to Teach Transcreation and Project Management Skills. Current Trends in Translation Teaching and Learning E, 8, 86 - 123. https://doi.org/10.51287/cttle2021

\section{REFERENCES}

Benetello, C. (2018). When translation is not enough:

Transcreation as a convention-defying practice. A practitioner's perspective. Jostrans: The Journal of Specialised Translation, 29, 28-44. https://www.jostrans.org/issue29/art_benetello.pd $\underline{\mathrm{f}}$

Bernal Merino, M. (2006). On the Translation of Video

Games. Jostrans: The Journal of Specialised Translation, 6, 22-36. https://www.jostrans.org/issue06/art_bernal.php

Botella Tejera, C., Carreira, O. \& Gamonal, N. (2021). Enseñar a transcrear: una propuesta didáctica para la formación en transcreación. In Beatriz Reverter Oliver, Juan José Martínez Sierra, Diana González-Pastor \& José Fernando Carrero Martín (Eds.). Modalidades de traducción audiovisual. Completando el espectro (pp. 53-66). Comares. 
Carreira, O. (2021). The Girl Up Project: A Proposal to Teach Transcreation and Project Management Skills. Current Trends in Translation Teaching and Learning E, 8, 86 - 123. https://doi.org/10.51287/cttle2021

Bowker, L., \& Fisher, D. (2010). Computer-aided translation. In Y. Gambier \& L. V. Doorslaer (Eds.), Handbook of Translation Studies - Volume 1. John Benjamins Publishing. https://doi.org/10.1075/hts.1

Calvo, E. (2015). Scaffolding translation skills through situated training approaches. The Interpreter and Translator Trainer, 9(3), 306-322. https://doi.org/10.1080/1750399X.2015.1103107

Carreira, O. (2020). The Transcreation Brief: A Definition Proposal. Transletters - International Journal of Translation and Interpreting, 3, 23-38. https://www.uco.es/ucopress/ojs/index.php/tl/artic le/view/12726

Chaume, F. (2018). Is audiovisual translation putting the concept of translation up against the ropes? Jostrans: The Journal of Specialised Translation, 30, 84-104. https://www.jostrans.org/issue30/art_chaume.php 
Carreira, O. (2021). The Girl Up Project: A Proposal to Teach Transcreation and Project Management Skills. Current Trends in Translation Teaching and Learning E, 8, 86 - 123. https://doi.org/10.51287/cttle2021

Chernatony, L. D., Harris, F., \& Dall'Olmo Riley, F. (2000). Added value: Its nature, roles and sustainability. European Journal of Marketing, 34(1/2), 39-56. https://doi.org/10.1108/03090560010306197

Courtney, J., \& Phelan, M. (2019). Translators' experiences of occupational stress and job satisfaction. The International Journal of Translation and Interpreting Research, 11(1), 100-113. http://www.transint.org/index.php/transint/article/view/848/330

Crosignani, S., \& Ravetto, F. (2011). ¡Coger el buzz! (O Como lograr la transcreación de un videojuego de ventas millonarias). Trans. Revista de traductología, 15, 29-38. https://doi.org/10.24310/TRANS.2011.v0i15.319 $\underline{3}$ 
Carreira, O. (2021). The Girl Up Project: A Proposal to Teach Transcreation and Project Management Skills. Current Trends in Translation Teaching and Learning E, 8, 86 - 123. https://doi.org/10.51287/cttle2021

De Campos, H. (2013). Metalinguagem \& outras metas: Ensaios de teoria et crítica literária. Perspectiva.

Dillon, S., \& Fraser, J. (2007). Translators and TM: An investigation of translators' perceptions of translation memory adoption. Machine Translation, 20(2), 67-79. https://doi.org/10.1007/s10590-006-9004-8

Doherty, S. (2016). The Impact of Translation Technologies on the Process and Product of Translation. International Journal of Communication, 10, 947-969. https://ijoc.org/index.php/ijoc/article/viewFile/34 $\underline{99 / 1573}$

Dybiec-Gajer, J., Oittinen, R., \& Kodura, M. (Eds.). (2020). Negotiating translation and transcreation of children's literature: from Alice to the Moomins. Springer International Publishing. 
Carreira, O. (2021). The Girl Up Project: A Proposal to Teach Transcreation and Project Management Skills. Current Trends in Translation Teaching and Learning E, 8, 86 - 123. https://doi.org/10.51287/cttle2021

Esselink, B. (2003). The Evolution of Localization. Localization: The Guide from Multilingual Computing and Technology, pp. 4-7. https://multilingual.com/downloads/screenSupp57 .pdf

García, I. (2009). Beyond Translation Memory:

Computers and the Professional Translator. Jostrans: The Journal of Specialised Translation, 12, 199-214.

https://www.jostrans.org/issue12/art_garcia.pdf

Glance, V., \& Jaccomard, H. (2019). A common space: translation, transcreation, and drama. The case of the English translation of the French play, On Arthur Schopenhauer's Sledgeby Yasmina Reza. TEXT, 57.

http://www.textjournal.com.au/speciss/issue57/G1 ance\&Jaccomard.pdf

Grönroos, C. (1997). Value-driven relational marketing: From products to resources and competencies. 
Carreira, O. (2021). The Girl Up Project: A Proposal to Teach Transcreation and Project Management Skills. Current Trends in Translation Teaching and Learning E, 8, 86 - 123. https://doi.org/10.51287/cttle2021

Journal of Marketing Management, 13(5), 407419.

https://doi.org/10.1080/0267257x.1997.9964482

Huertas Barros, E., \& Vine, J. (2019). Training the trainers in embedding assessment literacy into module design: A case study of a collaborative transcreation project. The Interpreter and Translator Trainer, 13(3), 271-291. https://doi.org/10.1080/1750399x.2019.1658958

International Organization for Standardization. (2015). ISO 17100 Translation services - Requirements for translation services.

Jones, J. P. (1986). What's in a name? Advertising and the concept of brands. Lexington Books.

Katan, D. (2016). Translation at the cross-roads: Time for the transcreational turn? Perspectives, 24(3), 365381.

https://doi.org/10.1080/0907676x.2015.1016049 
Carreira, O. (2021). The Girl Up Project: A Proposal to Teach Transcreation and Project Management Skills. Current Trends in Translation Teaching and Learning E, 8, 86 - 123. https://doi.org/10.51287/cttle2021

Kiraly, D. (2000). A Social Constructivist Approach to Translator Education: Empowerment from Theory to Practice. Manchester: St. Jerome Publishing.

—. (2005). Project-Based Learning: A Case for Situated Translation. Meta, 50(4), 1098-1111. https://doi.org/10.7202/012063ar

- (2016). Towards Authentic Experiential Learning in Translator Education. Göttingen: V\&R Academic Mainz University Press.

Koskinen, K., \& Dam, H. (2016). Academic boundary work and the translation profession: insiders, outsiders and (assumed) boundaries. Jostrans: The Journal of Specialised Translation, 25, 254267. https://www.jostrans.org/issue25/art_koskinen.pd f 
Carreira, O. (2021). The Girl Up Project: A Proposal to Teach Transcreation and Project Management Skills. Current Trends in Translation Teaching and Learning E, 8, 86 - 123. https://doi.org/10.51287/cttle2021

Kussmaul, P. (2000). A Cognitive Framework for Looking at Creative Mental Processes. In M. Olohan (Ed.), Intercultural Faultlines: Research models in translation studies: v. 1: Textual and cognitive aspects (pp. 57-72). Routledge.

Lal, P. (1996). Transcreation: Seven essays on the art of Transcreation. Writers Workshop.

Larsonneur, C. (2021). Neural Machine Translation: From Commodity to Commons? In R. Desjardins, C. Larsonneur, \& P. Lacour (Eds.), When Translation Goes Digital. Case Studies and Critical Reflections (pp. 257-280). Palgrave McMillan. https://doi.org/10.1007/978-3-030$\underline{51761-8}$

Lefevere, A. (2016). Translation, rewriting, and the manipulation of literary fame. Taylor \& Francis.

Liu, H. (2014, October). Chevy vs. Cadillac: What are translators and interpreters missing [Paper presentation]. Paper presented at a meeting of the 
Carreira, O. (2021). The Girl Up Project: A Proposal to Teach Transcreation and Project Management Skills. Current Trends in Translation Teaching and Learning E, 8, 86 - 123. https://doi.org/10.51287/cttle2021

New Zealand Society of Translators and Interpreters (NZSTI), Wellington, New Zealand. http://youtu.be/TK-jc2o1_gY

Malenova, E. D. (2017). Subtitling practice: From translation to Transcreation. Journal of Siberian Federal University. Humanities \& Social Sciences, 10(4), 526-536. $\underline{\text { https://doi.org/10.17516/1997-1370-0060 }}$

Mangiron, C. \& O’Hagan, M. (2006). Game Localisation: Unleashing Imagination with 'Restricted' Translation. Jostrans: The Journal of Specialised Translation, 6, 10-21.

https://www.jostrans.org/issue06/art_ohagan.pdf

McCracken, G. (2013). The value of the brand: an anthropological perspective. In D. A. Aaker \& A. L. Biel (Eds.), Brand equity \& advertising: Advertising's role in building strong brands. Psychology Press. 
Carreira, O. (2021). The Girl Up Project: A Proposal to Teach Transcreation and Project Management Skills. Current Trends in Translation Teaching and Learning E, 8, 86 - 123. https://doi.org/10.51287/cttle2021

Moorkens, J. (2017). Under pressure: Translation in times of austerity. Perspectives, 25(3), 464-477. https://doi.org/10.1080/0907676x.2017.1285331

Morón Martín, M. (2020). Transcreation as a Way to Promote Employability in Translation Training: Adding Value to Translation Training. HERMES Journal of Language and Communication in Business, 60, 125-139. https://doi.org/10.7146/hjlcb.v60i0.121315

Morón, M. \& Calvo, E. (2018). Introducing transcreation skills in translator training contexts: A situated project-based approach. Jostrans: The Journal of Specialised Translation, 29, 126-148.

https://www.jostrans.org/issue29/art_moron.pdf

Morón, M. \& Lobato, J. (2019). La transcreación de la moda á la mode: análisis de zonas de intervención en proyectos francés-español. Onomázein: Revista de lingüística, filología y traducción, 5, 
Carreira, O. (2021). The Girl Up Project: A Proposal to Teach Transcreation and Project Management Skills. Current Trends in Translation Teaching and Learning E, 8, 86 - 123. https://doi.org/10.51287/cttle2021

40-59.

https://www.jostrans.org/issue29/art_moron.pdf

Munday, J., \& Gambier, Y. (2014). A conversation between Yves Gambier and Jeremy Munday about transcreation and the future of the professions. Cultus: The Journal of Intercultural Mediation and Communication, 7, 20-36. http://www.cultusjournal.com/files/Archives/conv ersation_gambier_munday_3_p.pdf

Nord, C. (1991). Scopos, loyalty, and translational conventions. Target, 3(1), 91-109. https://doi.org/10.1075/target.3.1.06nor

Normann, R., \& Ramirez, R. (1994). Designing interactive strategy: From value chain to value constellation. John Wiley \& Sons.

O'Hagan, M. (2016). Translations| Massively Open Translation: Unpacking the Relationship Between Technology and Translation in the 21st Century. 
Carreira, O. (2021). The Girl Up Project: A Proposal to Teach Transcreation and Project Management Skills. Current Trends in Translation Teaching and Learning E, 8, 86 - 123. https://doi.org/10.51287/cttle2021

International Journal of Communication, 10, 929946.

https://ijoc.org/index.php/ijoc/article/view/3507

Pedersen, D. (2014). Exploring the concept of transcreation-transcreation as "more than translation'? Cultus: The Journal of Intercultural Mediation and Communication, 7, 57-71. http://www.cultusjournal.com/files/Archives/pede rsen_5_p.pdf

Qianyuan, G. (1995). Das Wesen des Übersetzens ist kreativ. Babel. Revue internationale de la traduction / International Journal of Translation, 41(3), 129-139.

https://doi.org/10.1075/babel.41.3.02qia

Sakamoto, A. (2021). The Value of Translation in the Era of Automation: An Examination of Threats. In R. Desjardins, R. C. Larsonneur, \& P. Lacour (Eds.), When Translation Goes Digital. Case Studies and Critical Reflections (pp. 231-255). Palgrave 
Carreira, O. (2021). The Girl Up Project: A Proposal to Teach Transcreation and Project Management Skills. Current Trends in Translation Teaching and Learning E, 8, 86 - 123. https://doi.org/10.51287/cttle2021

McMillan. https://doi.org/10.1007/978-3-030-

$\underline{51761-8 \_10}$

Sattler-Hovdar, N. (2019). Get Fit for the Future of Transcreation. Independent Publisher.

TAUS. (2019). TAUS Transcreation Best Practices and Guidelines. TAUS Signature Editions. https://info.taus.net/taus-transcreation-bestpractices-and-guidelines

Toral, A., \& Way, A. (2018). What Level of Quality Can Neural Machine Translation Attain on Literary Text? In J. Moorkens, S. Castilho, \& S. Doherty (Eds.), Translation Quality Assessment. Machine Translation: Technologies and Applications, vol 1 (pp. 263-287). Springer. https://doi.org/10.1007/978-3-319-91241-7_12

Vandegrift, D. (2016, June 10). Can artificial intelligence be creative? Medium. 
Carreira, O. (2021). The Girl Up Project: A Proposal to Teach Transcreation and Project Management Skills. Current Trends in Translation Teaching and Learning E, 8, 86 - 123. https://doi.org/10.51287/cttle2021

https://medium.com/@DavidVandegrift/canartificial-intelligence-be-creative-40e7eac56e 71

Van der Meer, J. (2016). A to-do list for the translation industry. TAUS Blog - TAUS. https://blog.taus.net/a-to-do-list-for-thetranslation-industry

Vermeer, H. (1996). A Skopos Theory of Translation (Some arguments for and against).Textcontext.

Williams, D. (2017, May 3). Why demand for localised content is booming. TranslateMedia. https://www.translatemedia.com/translationblog/demand-localised-content-booming/.

Yunker, J. (2002). Beyond borders: Web globalization strategies. New Riders. 